\title{
SENI MUSIK SERTA HUBUNGAN PENGGUNAAN PENDIDIKAN SENI MUSIK UNTUK MEMBENTUK KARAKTER PESERTA DIDIK DI SEKOLAH DASAR
}

\author{
Tri Juna Irawana ${ }^{1}$, Desyanri ${ }^{2}$, \\ Universitas Negeri Padang, Sumatera Barat, Indonesia ${ }^{1,2}$ \\ e-mail : trijunairawana50@gmail.com ${ }^{1}$,desyandri@ fip.unp.ac.id ${ }^{2}$,
}

\begin{abstract}
Abstrak
Seni memiliki peran yang sangat penting di dalam pendidikan. Misalnya seni dapat mempengaruhi perkembangan fisik dan mental peserta didik. Melalui pendidikan seni, perilaku peserta didik dapat terbentuk kearah yang lebih baik karena seni dapat mengenalkan nilai-nilai dan norma-norma yang ada dalam masyarakat kepada peserta didik. Pendidikan seni seperti seni musik memberikan kontribusi dalam proses pembelajaran seperti menyenangkan perasaan peserta didik, membuat peserta didik aktif, terciptanya kebersamaan antara peserta didik dengan guru, menumbuhkan rasa percaya diri, disiplin, kejujuran dan menyesuaikan pikiran perasaan dan tindakan. Dalam artikel ini akan dibahas tentang pengertian seni musik, jenis-jenis seni musik,manfaat seni musik, pengertian karakter peserta didik sekolah dasar, hubungan seni musik dengan pembentukan karakter peserta didik sekolah dasar. Musik tidak lagi sebagai mata pelajaran tambahan yang sewaktu-waktu bisa saja dihilangkan atau hanya sekedar pengisi waktu luang bagi anak-anak yang kursus musik. Terkait dengan itu, maka music merupakan sesuatu hal yang penting untuk membantu siswa dalam mengembangkan intelektual, emosional dan potensi-potensi yang ada dalam diri mereka. Hal ini merupakan salah satu tugas para pendidik untuk mewujudkan hal tersebut. Maka dari itu, music dalam pendidikan merupakan bagian penting yang apabila dimanfaatkan secara tepat akan secara efektif memberikan konstribusi yang berharga dalam mewujudkan tujuan pendidikan nasional. Untuk itu, maka melalui penelitian ini, akan dikembangkan model penanaman ideology nasional dan semangat perjuangan memlalui pembelajaran dengan mengintegrasikan music (lagu-lagu cinta tanah air dan perjuangan) pada tingkat sekolah dasar.
\end{abstract}

\section{Kata kunci: Seni Musik, Pendidikan Seni Musik, Karakter}

\begin{abstract}
Art has a very important role in education. For example art can affect the physical and mental development of students. Through art education, the behavior of students can be formed towards a better direction because art can introduce the values and norms that exist in society to students. Arts education such as music contributes to the learning process such as pleasing the feelings of students, making students active, creating togetherness between students and teachers, fostering self-confidence, discipline, honesty and adjusting thoughts, feelings and actions. In this article we will discuss about the notion of music art, types of music art, the benefits of music art, understanding the character of elementary school students, the relationship of music art with the formation of elementary school students' character.Music is no longer an additional subject that can be eliminated at any time or just fill in spare time for children who take music lessons. Related to that, music is something that is something that is important to help students develop their intellectual, emotional, and potentials within themselves.This is one of the tasks of educators to realize this. Therefore, music in education is an important part which if properly utilized will effectively make a valuable contribution in realizing the goals of national education. For this reason, this research will develop a national ideology planting model and the spirit of struggle through learning by integrating music (songs of love for the motherland and struggle) at the elementary school level.
\end{abstract}

Keywords: Art of Music, Art of Music Education, Character

@Edukasi: Jurnal Ilmu Pendidikan FIP UPTT 2019

$\triangle$ Corresponding author :

Address : Perumahan Tamiang Simpang Empat Pasaman Barat

Email : trijunairawana50@gmail.com

Phone : 081374928842
ISSN 2656-8063 (Media Cetak) ISSN 2656-8071 (Media Online) 


\section{PENDAHULUAN}

Pendidikan adalah investasi sumber daya manusia jangka panjang, yang mempunyai nilai strategis bagi kelangsungan peradaban manusia di dunia. Oleh sebab itu hampir semua Negara menempatkan variabel pendidikan sebagai sesuatu yang penting dan utama dalam konteks pembangunan bangsa dan negara. Begitu juga Indonesia menempatkan pendidikan sebagai sesuatu yang penting dan utama. Hal ini dapat dilihat dari isi Pembukaan UUD 1945 alinea IV yang menegaskan bahwa salah satu tujuan nasional bangsa Indonesia adalah mencerdaskan kehidupan bangsa. Dengan pendidikanlah seseorang dibekali dengan berbagai pengetahuan, keterampilan, keahlian dan tidak kalah pentingnya macam macam tatanan dalam kehidupan baik yang berupa norma - norma, aturan - aturan positif lainnya. Singkatnya pendidikan memungkinkan menjadikan manusia seutuhnya baik secara lahiriah maupun batiniah.

Selain Itu pendidikan juga berguna untuk membantu manusia untuk menjadi cerdas, pintar, dan berkarakter. Menjadikan manusia cerdas dan pintar boleh jadi lebih mudah melakukannya dibandingkan menjadikan manusia yang berkarakter.Kita sebagai guru hendaknya berusaha untuk mencapai tujuan pendidikan. Adapun bunyi undang-undang No.20 tahun 2003 tentang sistem pendidikan nasional yang menyatakan bahwa pendidikan adalah:

Usaha sadar dan terencana untuk mewujudkan suasana dan proses pembelajaran agar peserta didik secara aktif mengembangkan potensi dirinya untuk memiliki kekuatan spiritual keagamaan, pengendalian diri, kepribadian, kecerdasan, akhlak mulia, serta keterampilannya diperlukan masyarakat, dan Negara.

Di dalam undang-undang No.20 tahun 2003 diuraikan bahwa pendidikan harus mampu mengembangkan potensi yang ada pada diri peserta didik sehingga peserta didik cerdas dan berkarakter. Singkatnya pendidikan memungkinkan menjadikan manusia seutuhnya baik secara lahiriah maupun batiniah. Proses pendidikan terjadi pada jenjang jenjang pendidikan dan mengacu pada kurikulum sesuai dengan jenjang jenjang pendidikan.

Proses pendidikan melibatkan kegiatan atau proses belajar mengajar pada kegiatan belajar mengajar tersebut guru memiliki peran yang sangat penting. Proses kegiatan belajar mengajar tentu membutuhkan proses. Guru hendaknya mampu membuat proses pembelajaran yang menarik dan menyenangkan bagi peserta didik. Supaya tujuan pendidikan tercapai secara maksimal. Salah satu tujuan pendidikan itu adalah menghasilkan peserta didik yang berkarakter.

Karakter menjadi perhatian bangsa dalam mempersiapkan generasi yang berkualitas. Secara sederhana , pendidikan karakter dapat didefinisikan sebagai usaha yang dapat dilakukan untuk membentuk karakter siswa secara maksimal.

Pengembangan potensi peserta diri untuk menjadi perilaku yang baik bagi siswa yang telah memiliki sikap dan perilaku yang mencerminkan budaya dan karakter bangsa. Salah satu cara untuk mengembangkannya adalah dengan adanya mata pelajaran Seni Budaya dan Prakarya di sekolah dasar. Di dalam mata pelajaran Seni Budaya dan Prakarya ada pendidikan seni musik. Pendidikan seni musik di sekolah dasar adalah bentuk nyata dalam pembentukan karakter bangsa yang berbudaya, cinta tanah air, kreatif, kerjasama, disiplin dan tanggungjawab.

Perubahan keadaan zaman saat ini begitu pesat, hal ini mengakibatkan banyaknya dampakdampak positif maupun negatif yang bermunculan terutama terkait persoalan moral. Diberbagai media sosial banyak dijumpai postingan yang memperlihatkan tindak kekerasan, tawuran antar remaja dan perilaku-perilaku yang merusak diri seperti penyalahgunaan narkoba, pelecehan seksual hingga berani memosting foto maupun video dirinya sendiri dalam keadaan setengah telanjang. Dari semua persoalan moral ini, yang lebih memprihatinkan yakni pelaku dari tindakan tersebut dilakukan oleh para remaja dan anak-anak yang masih dalam usia yang sangat belia. Beberapa fenomena di atas disebabkan pada hilangnya karakter pada diri seorang siswa. Moral anak tidak akan rusak ketika dia memiliki karakter

Sekolah merupakan salah satu di antara sarana yang cukup efektif untuk melaksanakan, mengembangkan sekaligus mensukseskan agenda pendidikan karakter secara nasional karena dunia sekolah merupakan tempat bagi siswa menghabiskan waktu setelah di rumah. Artinya, perencanaan pelaksanaan pendidikan karakter yang dilaksanakan sebuah sekolah mempunyai peranan yang sangat penting dalam menentukan keberhasilan pendidikan karakter (Murniyetti, Engkizar, and Anwar 2016)

Pendidikan seni musik di sekolah dasar dapat meningkatkan semangat peserta didik dalam belajar danmembentuk karakter yang baik. Musik 
merupakan bunyi yang diterima oleh manusia yang berbeda-beda berdasarkan sejarah, tempat, budaya dan selera individu. Definisi tentang musik juga bermacam-macam di antaranya bahwa (1) musik adalah bunyi terhadap sesuatu yang ditangkap pendengaran, (2) musik adalah suatu karya seni dengan segenap unsur pokok dan pendukungnya, dan (3) musik adalah segala bunyi yang dihasilkan secara sengaja oleh seseorang atau oleh kelompok individu yang disajikan sebagai musik. Dari beberapa definisi tersebut, maka musik merupakan segala bunyi yang dihasilkan manusia secara sadar yang disajikan sebagai music. Berbagai penelitian menunjukkan bahwa untuk meningkatkan kecerdasan musik pada siswa dapat dilakukan dengan berbagai cara, di antaranya melalui (1) memperkenalkan musik di dalam kelas, (2) mendengarkan musik, (3) membuat instrumental musik di kelas. Untuk setiap tujuan, kelas diperkaya dengan musik dengan menggunakan berbagai macam cara.. Penggunaan musik di kelas akan membantu meningkatkan kegembiraan siswa dalam belajar dan sekaligus juga dapat meningkatkan efektivitas ketercapaian tujuan. Yang tidak kalah pentingnya belajar melalui musik dan atau belajar dengan musik, serta belajar tentang musik dapat memberikan banyak manfaat bagi perkembangan fisik maupun mental siswa. Melalui musik banyak yang dapat dipelajari oleh siswa di antaranya dikemukakan berikut ini(Halimah 2016)

Pendidikan seni musik merupakan pendidikan yang memberikan kemampuan mengekspresikan dan mengapresiasikan seni secara kreatif untuk pengembangan kepribadian siswa dan memberikan sikap-sikap atau emosional yang seimbang. Seni musik membentuk disiplin, toleransi, sosialisasi, sikap demokrasi yang meliputi kepekaan terhadap lingkungan. Dengan kata lain pendidikan seni musik merupakan mata pelajaran yang memegang peranan penting untuk membantu pengembangan individu siswa yang nantinya akan berdampak pada pertumbuhan akal, fikiran, sosialisasi, dan emosional.

Pendidikan seni musik merupakan suatu proses pendidikan yang membantu pengungkapan ide/gagasan seseorang yang ditimbulkan dari gejala lingkungan dengan mempergunakan unsurunsur musik, sehingga terbentuknya suatu karya musik yang tidak terlepas dari rasa keindahan.

Berdasarkan uraian tersebut nampak bahwa upaya pembentukan pribadi siswa mendapat porsi yang lebih utama dalam pembelajaran musik di sekolah. Hal ini sesuai dengan tujuan pendidikan nasional, yaitu membentuk manusia yang beriman dan bertakwa kepada Tuhan Yang Maha Esa, beretika (beradab dan berwawasan budaya bangsa Indonesia), memiliki nalar (maju, cukup cerdas, kreatif, inovatif, dan bertanggung jawab), berkemampuan komunikasi sosial (tertib dan sadar hukum, kooperatif dan kompetitif, demokratis), dan berbadan sehat sehingga menjadi manusia mandiri.

Jadi dapat disimpulkan Untuk membentuk karakter peserta didik, guru dalam proses pembelajaran tentu dituntut kemampuannya / kompetensi untuk melakukan tugas dalam pembelajaran secara professional, mewujudkan kinerjanya secara tepat dan efektif. Kompetensi pengetahuan, keterampilan dan nilai nilai dasar hendaknya direalisasikan dalam kebiasaan berpikir dan bertindak. Profesionalisme guru tidak hanya sebagai pengajar tetapi juga bertugas memotivasi peserta didik untuk bekerja keras dan mencapai prestasi setinggi tingginya dan membantu siswa menghargai nilai belajar dan pengetahuan, Kemudian membimbing siswa menjadi teladan mengeluarkan ide ide yang dimilikinya. Dengan peran tersebut diharapkan dapat menumbuhkan kecerdasan moral siswa secara kompetitif dan membentuk peserta didik yang berkarakter.

\section{METODE PENELITIAN}

Pendidikan seni musik adalah suatu yang sangat diperlukan untuk membentuk karakter peserta didik sekolah dasar. Di sekolah dasar pendidikan seni musik ini masuk dalam mata pelajaran Seni Budaya dan Prakarya. Di sekolah dasar penggunaan seni music ini untuk pembentukan karakter siswa belum maksimalkan digunakan. Jadi, artikel ini bertujuan memaparkan tentang peran seni music untuk pembentukan karakter peserta didik. Penlitian ini menggunakan pendekatan kualitatif dengan metode analisis konseptual yang bersifat deskriptif. Penelitian ini menggunakan metode analisis konseptual yang mengkaji berbagai literatur untuk memecahkan permasalahan.

\section{HASIL DAN PEMBAHASAN}

Undang-Undang No. 20 Tahun 2003 tentang Sistem Pendidikan Nasional Pasal 1 ayat (1) menegaskan bahwa pendidikan merupakan usaha 
sadar dan terencana untuk mewujudkan suasana belajar dan proses pembelajaran agar peserta didik secara aktif mengembangkan potensi dirinya untuk memiliki kekuatan spiritual keagamaan, pengendalian diri, kepribadian, kecerdasan, akhlak mulia serta keterampilan yang diperlukan dirinya, masyarakat, bangsa dan negara.

Seni merupakan istilah yang identik dengan keindahan, kesenangan, dan rekreasi. Saat kita mendengar kata seni maka yang mungkin muncul dalam benak kita adalah suatu karya seni entah berupa benda, music, bangunan, lukisan atau benda-benda indah lainnya yang dihasilkan oleh seorang seniman yang tentunya sangat berbakat dan memiliki kreativitas yang tinggi. Dalam dunia pendidikan, seni juga memberikan pengaruh penting terhadap perkembangan mental maupun fisik siswa. Bahkan, dengan pendidikan seni, perilaku siswa dapat terbentuk kearah yang lebih baik karena seni dapat mengenalkan nilai-nilai dan norma-norma yang ada dalam masyarakat kepada siswa.

Musik merupakan karya cipta manusia memakai medium bunyi untuk menikmatinya. Musik hadir dalam bentuk kesatuan irama, melodi, harmoni, bentuk dan gaya, serta ekspresi.Musik itu sendiri meliputi tidak hanya instrumen saja, tetapi juga vokal. Hal ini berarti ketika seseorang mengetahui cara memainkan musik, belum dapat dikatakan sebagai pemusik apabila ia tidak memahami teknik vokal.Demikian pula sebaliknya.

Rien (1999:1) seni musik adalah suatu hasil karya dalam bentuk lagu atau komposisi musik yang mengungkapkan pikiran dan perasaan penciptanya melalui unsur-unsur musik yaitu irama, melodi, harmoni, bentuk lahu, dan ekspresi.

Dengan adanya musik seseorang dapat mengungkapkan perasaannya meskipun dari berbagai ungkapan perasaan seseorang berbedabeda. Pembelajaran musik di Sekolah Dasar diberikan secara bertahap yang sesuai dengan tingkat perkembangan siswa.

Pengertian seni music bermacam-macam di antaranya yaitu (1) musik adalah bunyi/kesan terhadap sesuatu yang ditangkap pendengaran , (2) musik adalah suatu karya seni dengan beberapa unsur pokok dan pendukungnya, dan (3) musik adalah segala bunyi yang dihasilkan secara sengaja oleh seseorang kelompok individu yang disajikan sebagai musik. Dari beberapa definisi tersebut, maka musik merupakan segala bunyi yang dihasilkan manusia secara sengaja yang disajikan sebagai music. Berbagai penelitian menunjukkan bahwa untuk meningkatkan kecerdasan musik pada siswa dapat dilakukan dengan berbagai cara, di antaranya melalui (1) memperkenalkan musik di dalam kelas, (2) mendengarkan musik, (3) membuat instrumental musik di kelas. Untuk setiap tujuan, kelas diperkaya dengan musik dengan menggunakan beragam teknik secara bervariasi. Penggunaan musik di kelas akan membantu meningkatkan kegembiraan siswa dalam belajar dan sekaligus juga dapat meningkatkan efektivitas ketercapaian tujuan. Yang tidak kalah pentingnya belajar melalui musik dan atau belajar dengan musik, serta belajar tentang musik dapat memberikan banyak manfaat bagi perkebangan baik fisik maupun mental siswa(Halimah 2016)

Pendidikan seni musik memiliki peran dan manfaat yang dominan dalam dunia pendidikan. Pendidikan seni, khususnya seni musik secara historis telah ada sejak dulu di seluruh belahan bumi. Kepekaan dan kreativitas anak dalam seni musik menjadi salah satu indikator keberhasilan pendidikan dan pencapaian prestasi anak. Pendidikan seni musik meliputi keterampilan bermusik, penanaman nilai- nilai etika dan estetika, serta sarana ekspresi dan kreativitas anak. Pergeseran paradigma pendidikan seni musik sebatas pada pengajaran keterampilan bermusik dan sebagai pelepas kepenatan anak saat belajar perlu diluruskan. Paradigma yang lebih tepat dalam memandang pendidikan seni musik ini dapat diluruskan dengan redefinisi pendidikan seni musik bagi anak dengan bertolak dari penggalian kembali esensi pendidikan seni musik, peranan seni musik, karakteristik pendidikan seni musik, dan manfaat yang dapat diambil dari pendidikan seni musik(Respati 2015)

Pendidikan seni musik lebih menekankan pada pemberian pengalaman seni musik, yang nantinya akan melahirkan kemampuan untuk memanfaatkan seni musik pada kehidupan seharihari. Pendidikan Seni musik diberikan di sekolah karena keunikan, kebermaknaan, dan kebermanfaatan terhadap kebutuhan perkembangan siswa, yang terletak pada pemberian pengalaman estetik dalam bentuk kegiatan berekspresi/berkreasi dan berapresiasi melalui pendekatan: "belajar dengan seni," "belajar melalui seni" dan "belajar tentang seni." 
Pendekatan ini menekankan pada proses pemerolehan dan pemahaman pengetahuan yang didapatkan dengan kegiatan seni musik misalnya siswa belajar menyanyikan lagu Indonesia Raya, maka dengan mempelajari lagu tersebut siswa dapat mengetahui dan memahami sikap apa yang terdapat pada lagu. Siswa seharusnya tahu tentang apa yang diceritakan lagu, dan dari pengetahuan tersebut siswa bisa mengambil suatu kesimpulan bahwa lagu Indonesia Raya menginginkan terwujudnya sikap cinta tanah air, kebanggaan terhadap tanah air, dan sikap mempertahankan tanah air, serta menanamkan jiwa patriotis.

Pendekatan ini menekankan pada pemahaman emosional yang tercermin ke dalam penanaman nilai-nilai atau sikap yang terbentuk melalui kegiatan berkesenian. Seperti dalam menyanyikan sebuah lagu, dituntut untuk membuat keteraturan tempo/ketukan. Apabila kita tidak bisa mengikuti tempo tersebut, maka lagu yang dibawakan menjadi kacau atau tidak.

Kata character berasal dari bahasa Yunani charassein, yang berarti to engrave (melukis, menggambar), seperti orang yang melukis kertas, memahat batu atau metal. Berakar dari pengertian yang seperti itu, character kemudian diartikan sebagai tanda atau ciri yang khusus, dan karenanya melahirkan sutu pandangan bahwa karakter adalah ,pola perilaku yang bersifat individual, keadaan moral seseorangee. Setelah melewati tahap anakanak, seseorang memiliki karakter, cara yang dapat diramalkan bahwa karakter seseorang berkaitan dengan perilaku yang ada di sekitar dirinya (Kevin Ryan, 1999:5)

Istilah karakter dihubungkan dan dipertukarkan dengan istilah etika, ahlak, dan atau nilai dan berkaitan dengan kekuatan moral, berkonotasi "positif” bukan netral. Oleh karena itu Pendidikan karakter secara lebih luas dapat diartikan sebagai pendidikan yang mengembangkan nilai budaya dan karkter bangsa pada diri peserta didik sehingga mereka memiliki nilai dan karakter sebagai karakter dirinya, menerapkan nilai-nilai tersebut dalam kehidupan dirinya sebagai anggota masyarakat, dan warga negara yang religius, nasionalis, produktif, dan kreatif.

Karakter yang baik berkaitan dengan mengetahui yang baik (knowing the good), mencintai yang baik (loving the good), dan melakukan yang baik (acting the good). Ketiga ideal ini satu sama lain sangat berkaitan. Seseorang lahir dalam keadaan bodoh, dorongandorongan primitif yang ada dalam dirinya kemungkinan dapat memerintahkan atau menguasai akal sehatnya. Maka, efek yang mengiringi pola pengasuhan dan pendidikan seseorang akan dapat mengarahkan kecenderungan, perasaan, dan nafsu besar menjadi beriringan secara harmoni atas bimbingan akal dan juga ajaran agama.

Dalam Undang-Undang No. 20 Tahun 2003 tentang Sistem Pendidikan Nasional Pasal 1ayat (1) menegaskan bahwa pendidikan merupakan usaha sadar dan terencana untuk mewujudkan suasana belajar dan proses pembelajaran agar peserta didik secara aktif mengembangkan potensi dirinya untuk memiliki kekuatan spiritual keagamaan, pengendalian diri, kepribadian, kecerdasan, akhlak mulia serta keterampilan yang diperlukan dirinya, masyarakat, bangsa dan negara. Berdasarkan pengertian pendidikan di atas maka kegiatan pokok dalam pendidikan adalah belajar. Seni memberikan pengaruh penting terhadap perkembangan mental maupun fisik siswa. Bahkan, dengan pendidikan seni, perilaku siswa dapat terbentuk kearah yang lebih baik karena seni dapat mengenalkan nilai-nilai dan norma-norma yang ada dalam masyarakat kepada siswa.

Adapaun fungsi seni musik antara lain: (1) fungsi religi, (2) fungsi komunikasi, (3) fungsi rekreasi, (4)fungsi artistik, (5) fungsi guna dan (6) terapi. Fungsi seni musik yang lain yaitu

(1)membantu pertumbuhan dan perkembangan siswa (2) membina perkembangan estetika siswa dalam berkarya seni.

Seni Budaya dan Keterampilan (SBK) sebagai salah satu bidang studi dalam pembelajaran dengan melihat latar belakang akan dapat menumbuhkan kecerdasan moral secara kompetitif, latar belakang tersebut sebagai berikut, yaitu bahwa muatan seni budaya dan keterampilan sebagaimana yang diamanatkan dalam peraturan Pemerintah Republik Indonesia Nomor 19 tahun 2005 tentang Standar Nasional Pendidikan tidak hanya dalam satu mata pelajaran karena budaya itu sendiri meliputi segala aspek kehidupan. Dalam mata pelajaran Seni Budaya dan Keterampilan, aspek budaya tidak dibahas secara tersendiri tetapi terintegrasi dengan seni. Karena itu mata pelajaran Seni Budaya dan Keterampilan pada dasarnya 
merupakan pendidikan seni yang berbasis budaya.Pendidikan seni budaya dan Keterampilan diberikan di sekolah karena keunikan, kebermaknaan, dan kebermanfaatan terhadap kebutuhan perkembangan peserta didik. Yang terletak pemberian pengalaman estetik dalam bentuk kegiatan berekspresi /berkreasi melalui pendekatan: "belajar dengan seni" "belajar melalui seni" dan "belajar tentang seni." Peran ini tidak dapat diberikan oleh mata pelajaran lain.

Tidak dapat diragukan lagi betapa penting dan strategisnya pendidikan dalam pembangunan suatu bangsa. Pendidikan adalah investasi sumber daya manusia jangka panjang, yang mempunyai nilai strategis bagi kelangsungan peradaban manusia di dunia. Oleh sebab itu hampir semua Negara menempatkan variabel pendidikan sebagai sesuatu yang penting dan utama dalam konteks pembangunan bangsa dan negara. Begitu juga Indonesia menempatkan pendidikan sebagai sesuatu yang penting dan utama. Hal ini dapat dilihat dari isi Pembukaan UUD 1945 alinea IV yang menegaskan bahwa salah satu tujuan nasional bangsa Indonesia adalah mencerdaskan kehidupan bangsa. Dengan pendidikanlah seseorang dibekali dengan berbagai pengetahuan, keterampilan, keahlian dan tidak kalah pentingnya macam macam tatanan dalam kehidupan baik yang berupa norma - norma, aturan - aturan positif lainnya. Singkatnya pendidikan memungkinkan menjadikan manusia seutuhnya baik secara lahiriah maupun batiniah. Proses pendidikan terjadi pada jenjang jenjang pendidikan dan mengacu pada kurikulum sesuai dengan jenjang jenjang pendidikan

tersebut, proses pendidikan melibatkan kegiatan / proses belajar mengajar pada kegiatan belajar mengajar tersebut guru menjadi kuncinya . Siapapun tidak akan pernah menyangkal bahwa kegiatan belajar mengajar tidak berproses dalam kehampaan, tetapi dengan penuh makna Kegiatan belajar mengajar adalah suatu kondisi yang dengan sengaja diciptakan gurulah yang menciptakannya guna membelajarkan siswanya, guru yang mengajar dan siswa yang belajar perpaduan dari kedua unsur manusia ini lahirlah interaksi edukatif dengan memanfaatkan bahan bahan sebagai mediumnya. Sebagai guru sudah menyadari apa yang sebaiknya dilakukan untuk menciptakan kondisi belajar mengajar yang dapat mengantarkan siswa ke tujuan yang mampu menumbuhkan kecerdasan moral secara kompetitif.
Kecerdasan merupakan sikap intelektual mencakup ketepatan memberikan jawaban, penyelesaian dan kemampuan memecahkan masalah (Munzert, A.W. (1994). Kecerdasan tidak hanya dipahami sekedar sebagai intelektual (IQ) tetapi juga kecerdasan emosional (EQ), kecerdasan sosial (SQ), dan sebagainya (RadnoHarsanto, 2007: 24). David Wescher memberikan rumusan kecerdasan sebagai suatu kapasitas umum dari individu untuk bertindak, berpikir rasional dan berinteraksi dengan lingkungan secara efektif.

Hakikat belajar mengajar dalam kegiatan belajar mengajar anak sebagai subjek dan objek dari kegiatan pengajaran karena itu inti proses pengajaran tiada lain adalah kegiatan belajar anak didik dalam mencapai suatu tujuan pengajaran. Tujuan pengajar tentu saja akan tercapai jika anak berusaha aktif mencapainya. Keaktifan anak disini tidak hanya dituntut dari segi fisik tetapi dari segi kejiwaan, bila hanya fisik yang aktif tetapi pikiran dan mentalnya kurang aktif maka kemungkinan besar tujuan pembelajaran tidak akan tercapai. Ini sama halnya dengan anak didik tidak belajar, karena anak didik tidak merasakan perubahan dalam dirinya. Padahal belajar pada hakikatnya adalah "perubahan" yang terjadi pada seseorang setelah berakhirnya melakukan aktivitas belajar. Sama halnya dengan belajar, mengajar pun pada hakikatnya adalah suatu proses yaitu proses mengatur, mengorganisasi lingkungan yang ada sekitar anak sehingga dapat menumbuhkan dan mendorong anak didik melakukan proses belajar. Pada tahap berikutnya mengajar adalah proses memberikan bimbingan / bantuan kepada anak didik dalam melakukan proses belajar

Akhirnya bila belajar adalah "perubahan", maka hakikat belajar mengajar adalah proses ditandai dengan aktivitas anak didik sebagai konsekuensi bahwa anak didik merupakan syarat mutlak bagi berlangsungnya kegiatan belajar mengajar, peran guru sebagai pembimbing harus memotivasi “ pengaturan' yang dilakukan guru. Komponen komponen belajar mengajar, sebagai suatu sistem tentu saja kegiatan belajar mengajar mengandung sejumlah komponen antara lain yang meliputi tujuan,adalah suatu cita cita yang ingin dicapai dari pelaksanaan suatu kegiatan; bahan pelajaran,adalah substansi yang akan disampaikan dalam proses belajar mengajar; kegiatan belajar mengajar, adalah kegiatan inti dalam pendidikan, dalam tersebut akan melibatkan semua komponen pengajaran kegiatan belajar akan menentukan 
sejauh mana tujuan yang telah ditetapkan telah tercapai.

Metode adalah suatu cara yang dipergunakan untuk mencapai tujuan; alat adalah segala sesuatu yang dapat digunakan dalam rangka mencapai tujuan pengajaran alat dibagi dalam dua macam yaitu alat dan alat bantu pengajaran atau alat material \&nonmaterial; sumber belajar adalah segala sesuatu yang dapat digunakan sebagai tempat dimana bahan pengajaran terdapat atau asal untuk belajar seseorang (Udin SyaripuddinWinataputra :1991)

Evaluasi adalah suatu tindakan / proses untuk menentukan nilai sebagai sesuatu dalam pendidikan / segala sesuatu yang ada hubungannya dengan pendidikan. Ciri ciri belajar mengajar sebagai suatu proses pengaturan kegiatan belajar mengajar tidak terlepas dari ciri-ciri tertentu yaitu sebagai berikut: 1) belajar mengajar memiliki tujuan yakni membentuk anak didik dalam suatu perkembangan tertentu, 2) ada suatu prosedur (jalannya interaksi) yang direncanakan, didesain untuk mencapai tujuan tertentu, 3) ditandai dengan satu penggarapan materi yang khusus, 6) dalam kegiatan belajar mengajar membutuhkan disiplin, disiplin dalam kegiatan belajar mengajar diartikan sebagai suatu pola tingkah laku yang diatur sedemikian rupa menurut ketentuan yang sudah ditaati, 7) ada batas waktu, untuk mencapai tujuan pembelajaran tertentu batas waktu menjadi salah satu yang tidak bisa ditinggalkan.

Setiap tujuan akan diberi waktu tertentu kapan tujuan itu sudah kegiatan diatas masalah evaluasi bagian yang tidak bisa diabaikan setelah melaksanakan kegiatan belajar mengajar evaluasi harus dilakukan untuk mengetahui tercapai tidaknya tujuan pengajaran yang telah ditentukan Keberhasilan belajar mengajar untuk menyatakan bahwa suatu proses belajar mengajar dapat dikatakan berhasil sebaiknya kita berpedoman pada kurikulum yang berlaku saat ini antara lain " Suatu proses belajar tentang suatu bahan pengajaran dinyatakan berhasil apabila tujuan instruksional khusus (tik) -nya dapat tercapai". Arti dan makna pembelajaran, pembelajaran adalah membelajarkan siswa menggunakan asas pendidikan maupun teori belajar merupakan penentu utama keberhasilan pendidikan. Pembelajaran merupakan proses komunikasi dua arah mengajar dilakukan oleh pihak guru sebagai pendidik, sedangkan belajar dilakukan oleh peserta didik.
Konsep pembelajaran menurut Corey ( 1986:195) adalah suatu proses dimana lingkungan seseorang secara disengaja dikelola untuk memungkinkan ia turut serta dalam tingkah laku tertentu dalam kondisi kondisi khusus atau menghasilkan respons terhadap situasi tertentu, pembelajaran merupakan subset khusus dari pendidikan Pembelajaran mengandung arti setiap kegiatan yang dirancang untuk membantu seseorang mempelajari suatu kemampuan dan atau nilai yang baru. Untuk memahami lebih mendalam pembelajaran menurut Dimyati Mudjiono (1999: 297) kegiatan guru untuk secara terprogram dalam desain instruksional, untuk membuat siswa belajar secara aktif, yang menekankan pada penyediaan sumber belajar.

Pembelajaran mempunyai dua karakteristik yaitu; pertama dalam proses pembelajaran melibatkan bukan hanya menuntut siswa sekedar mendengar, mencatat, akan tetapi menghendaki aktivitas siswa dalam proses berpikir. Kedua, dalam pembelajaran membangun suasana dialogis dan proses tanya jawab terus menerus yang diarahkan untuk memperbaiki dan meningkatkan kemampuan berpikir siswa, yang pada gilirannya kemampuan berpikir itu dapat membantu siswa untuk memperoleh pengetahuan yang mereka konstruksi sendiri. Kecerdasan tidak dipahami sekedar kecerdasan intelektual (IQ), tetapi juga kecerdasan emosional (EQ), kecerdasan sosial (SQ) dan dan sebagainya.

Pada hakekatnya pendidikan karakter/moral memiliki dua tujuan, yaitu membantu manusia untuk menjadi cerdas spiritual, social, pengetahuan dan keterampilan. Maka dari itu seorang pendidik tidak hanya dituntut menjadi pengajar tetapi sekaligus mendidik yakni dengan memberikan nilai-nilai moral baik pada siswa yang di mulai sejak ia dini. Oleh sebab itulah kemudian pemerintah menurunkan kebijakan pergantian kurikulum dari KTSP menjadi Kurikulum 2013. Kurikulum 2013 ini lebih menekankan pada penanaman karakter dan budaya kepada siswa yang dimulai sejak usia dini.3 Dalam strategi implementasinya pemerintah menyediakan buku siswa dan buku guru sebagai buku wajib sumber belajar di sekolah. Buku tersebut diluncurkan berupa cetak dan E-book.

Buku selain sebagai sarana untuk mentransformasikan pengetahuan di dalamnya juga termuat nilai-nilai karakter agar tercapainya tujuan dari tiap pembelajaran. Ditinjau dari fungsi dan peranan buku teks yang sangat berpengaruh 
dalam hasil pembelajaran, maka buku tersebut harus memiliki kualitas yang baik. Semakin baik kualitas buku pelajaran, maka semakin sempurna pengajaran mata pelajaran yang ditunjangnya. Buku ajar yang dapat dikatakan baik yaitu buku yang materi/isi dalam buku siswa sesuai dengan pendidikan karakter tuntutan kurikulum yang berkaitan dan berkualitas, mengacu pada sasaran yang akan dicapai peserta didik yakni kesesuain antara KI dan KD.

Terdapat beberapa karakter perkembangan anak usia dini. Diantaranya adalah perkembangan jasmani (fisik dan motorik), perkembangan kognitif, perkembangan berbicara, per-kembangan emosi, perkembangan sosial, dan perkembangan moral. Anak usia dini mempunyai cara belajar tersendiri yang berbeda dengan orang dewasa. Pada umumnya rentangan usia dini masih melihat segala sesuatu sebagai satu keutuhan (holistik) sehingga pembelajarannya masih bergantung pada objek - objek konkret dan pengalaman yang dialaminya.(Aminah 2016).

Musik adalah bunyi yang diterima oleh individu dan berbeda-beda berdasarkan sejarah, lokasi, budaya dan selera individu. Definisi sejati tentang musik juga bermacam-macam di antaranya bahwa (1) musik adalah bunyi/kesan terhadap sesuatu yang ditangkap oleh indera pendengar, (2) musik adalah suatu karya seni dengan segenap unsur pokok dan pendukungnya, dan (3) musik adalah segala bunyi yang dihasilkan secara sengaja oleh seseorang atau oleh kelompok individu yang disajikan sebagai musik. Dari beberapa definisi tersebut, maka musik merupakan segala bunyi yang dihasilkan manusia secara sengaja yang disajikan sebagai music. Berbagai penelitian menunjukkan bahwa untuk meningkatkan kecerdasan musik pada siswa dapat dilakukan dengan berbagai cara, di antaranya melalui (1) memperkenalkan musik di dalam kelas, (2) mendengarkan musik, (3) membuat instrumental musik di kelas. Untuk setiap tujuan, kelas diperkaya dengan musik dengan menggunakan beragam teknik secara bervariasi. Penggunaan musik di kelas akan membantu meningkatkan kegembiraan siswa dalam belajar dan sekaligus juga dapat meningkatkan efektivitas ketercapaian tujuan. Yang tidak kalah pentingnya belajar melalui musik dan atau belajar dengan musik, serta belajar tentang musik dapat memberikan banyak manfaat bagi perkembangan baik fisik maupun mental siswa.
Musik merupakan bagian dari kehidupan oleh karena itu, musik berhubungan dengan pengalaman sekolah. Telah banyak hasil penelitian yang mengungkapkan bahwa musik telah digunakan untuk memberikan motivasi di bidang matematika, ilmu sosial, bahasa seni, ilmu pengetahuan, sejarah, dan sebagainya. Musik adalah bahasa universal, sehingga dapat diintegrasikan dalam semua bidang studi untuk memberikan pembelajaran. Karena musik dapat membantu sekolah menjadi tempat yang menyenangkan, dan music menjadi milik anakanak bersama. Dengan demikian, guru harus mengambil keuntungan dari motivasi belajar yang distimuli dengan music ini. Untuk mengintegrasikan music dalam pembelajaran, dapat dilakukan melalui berbagai strategi. Seperti pada saat pembelajaran, guru dapat memutar musik untuk menciptakan relaksasi dan kegairahan siswa. Musik menjadi pembangkit motivasi siswa. Mereka bergairah mengikuti kegiatan belajar dan melepas ketegangan dalam menyelesaikan kegiatan.

Penggunaan musik di kelas akan membantu meningkatkan kegembiraan siswa dalam belajar dan sekaligus juga dapat meningkatkan efektivitas ketercapaian tujuan. Yang tidak kalah pentingnya belajar melalui musik dan atau belajar dengan musik, serta belajar tentang musik dapat memberikan banyak manfaat bagi perkebangan baik fisik maupun mental siswa. Melalui musik banyak yang dapat dipelajari oleh siswa di antaranya membantu siswa mengingat pengalaman belajar dan membuat siswa aktif, pengalaman musik dilakukan melalui menciptakan sebuah soundtrack untuk kegiatan belajar. Soundtrack mampu meningkatkan minat dan mengaktifkan informasi secara mental, fisik, atau emosional. Musik juga dapat menciptakan kondisi pembelajaran yang sangat terfokus, di mana kosakata dan bahan bacaan diserap pada tingkat yang besar. Jika informasi dikemas melalui irama dan sajak, unsur-unsur musik ini akan menyediakan sebuah kaitan untuk ingatan.

Berikut adalah tiga cara yang dapat dilakukan guru dalam menggunakan musik untuk membantu siswa belajar informasi. 1) Pengalaman Aktif Belajar Musik akan mengaktifkan siswa secara mental, fisik, dan emosional dan menciptakan pusat minat terhadap apa yang dipelajari sehingga dapat meningkatkan pemahaman tentang materi pembelajaran. Misalnya pada kelas IPS, saat siswa membaca 
materi sejarah perjuangan bangsa, sambil mendengarkan musik yang berirama perjuangan, maka musik tersebut akan membantu siswa untuk memahami materi tentang perjuangan tersebut. Pembelajaran akan semakin menarik dan semakin efektif, manakala dilanjutkan dengan kegiatan bermain peran dengan musik latar tetap mengalun. Materi pelajaran akan dipahami dengan sangat baik dan mudah diingat karena musik membantu siswa untuk menghargai pengalaman dan mengatur suasana hati. 2) Fokus dan Alpha Minat Belajar Musik menstabilkan mental, fisik dan irama emosional untuk mencapai keadaan konsentrasi mendalam dan fokus di mana sejumlah besar konten informasi dapat diproses dan dipelajari. Musik barok, seperti yang digubah oleh Bach, Handel atau Telemann, yaitu 50-80 denyut per menit menciptakan suasana fokus yang mengarah ke dalam konsentrasi siswa dalam keadaan gelombang otak alfa. Belajar kosakata, menghafal fakta atau membaca yang diiringi musik ini sangat efektif. Di sisi lain, energi musik Mozart membantu dalam mempertahankan perhatian selama waktu mengantuk, dan membantu siswa untuk tetap waspada saat membaca atau bekerja pada proyek-proyek. 3) Menghafal Lagu, nyanyian, puisi, dan ketukan yang berirama musik akan meningkatkan isi memori fakta dan rincian melalui rima, irama, dan melodi. Maksudnya materi yang dikemas dalam lagu, nyanyian, dan puisi yang ditulis sendiri oleh siswa akan menjadi alat memori yang hebat.

Meningkatkan Perhatian, Sikap, dan Atmosper Musik tertentu akan menciptakan suasana belajar yang positif dan membantu siswa untuk merasa diterima untuk berpartisipasi dalam pengalaman pembelajaran. Dengan cara ini juga telah sangat mempengaruhi siswa pada sikap dan motivasi untuk belajar. Irama dan tempo suara musik dapat membantu siswa dalam menetapkan dan mempertahankan fokus perhatiannya dan tetap bersemangat, sekalipun mereka ada dalam keadaan letih lesu. Juga membantu mereka menemukan damai dan tenang ketika mereka terlalu bersemangat dalam beberapa cara. Berikut adalah dua cara untuk menggunakan musik dalam membangun sikap, perhatian dan suasana. 1) Menyambut dan Perhatian Musik latar dapat digunakan untuk memberikan suasana yang bersahabat dan membantu mempersiapkan dan memotivasi siswa untuk tugas-tugas belajar. Musik dapat memberikan energi untuk meningkatkan perhatian atau memberikan ketenangan ketika diperlukan. Saat siswa memasuki ruang kelas mendengar musik mengalun atau saat mereka pergi untuk istirahat atau makan siang mendengar musik mengalun pula, suasana seperti itu benarbenar dapat mengubah atmosfer suasana hati. Tentu untuk membuat atmosfer yang menekankan pada suasana menyambut, meminta perhatian, atau bahkan untuk suatu perpisahan diperlukan musik yang tepat. Dengan kata lain, apa musik yang tepat manakala siswa masuk kelas, dan manakala guru meminta perhatian pada siswa, begitu pula saat siswa harus meninggalkan kelas. Dalam hal ini, guru dapat memilih musik yang penuh semangat, musik yang menciptakan ketenangan, musik yang dapat menghidupkan suasana, atau musik yang bertemakan untuk memberikan informasi terkait materi pelajaran, dan sebagainya.

Membangun Masyarakat Belajar Musik menyediakan lingkungan yang positif yang meningkatkan interaksi siswa dan membantu mengembangkan rasa kebersamaan dan kerjasama. Musik adalah alat yang ditempuh untuk memahami budaya sendiri dan juga budaya lain dan dapat menjadi ikatan dengan satu sama lainnya. Memilih dan memainkan lagu tema kelas, mengembangkan ruang kelas "ritual" seperti menggunakan musik untuk menyapa dengan hello misalnya pada saat mau bekerja kelompok, atau selamat tinggal saat selesai kegiatan kelompok atau kegiatan kelompok lainnya. Menggunakan musik baik sebelum, selama, atau setelah kegiatan belajar bersama adalah cara yang baik untuk membangun pengalaman komunitas yang langgeng.

Ekspresi Pribadi Musik adalah pintu ke alam batin dan penggunaan musik yang kreatif dan reflektif dapat memfasilitasi ekspresi pribadi baik dalam menulis, seni, gerakan, dan kegiatan belajar lainnya. Penciptaan komposisi musik menawarkan jalur untuk mengungkapkan perasaan dan keyakinan pribadi dalam bahasa suara musik. Berikut adalah dua cara, bahwa musik dapat membantu siswa untuk mengungkapkan diri sendiri. 1) Kreativitas dan Perenungan Musik latar dapat digunakan untuk merangsang proses internal, untuk memfasilitasi kreativitas, dan mendorong refleksi pribadi. Memperdengarkan musik, seperti piano solo baik dalam gaya klasik maupun kontemporer, pada saat siswa menulis laporan, menulis atau mengarang, menulis jurnal, atau menulis terkait proyek belajarnya mampu memusatkan perhatian pada waktu yang lebih lama daripada tanpa musik. Dalam sebuah studi, siswa 
menulis dua kali lebih banyak bila diiringi musik daripada tanpa musik. 2) Ekspresi Pribadi melalui situs Intelijen Menciptakan musik untuk mengungkapkan pikiran dan perasaan batin dan mengembangkan kecerdasan musikal melalui pemahaman irama, pitch, dan bentuk. Menulis lagu yang terkait dengan konten atau materi pelajaran memungkinkan siswa untuk mengungkapkan bagaimana perasaan mereka. Misalnya menulis lagu tentang isu-isu penting terkait insiden bersejarah, merangkai peristiwa bersejarah dalam sebuah syair lagu dari topik ilmu sosial atau

menulis puisi terkait kondisi sosial, ekonomi, politik sejalan dengan kondisi saat ini.

Siswa juga dapat menciptakan instrumental "soundtrack" dengan irama sederhana instrumen yang menggambarkan auditorily yang sangat penting tentang penemuan ilmiah, peristiwa sejarah, atau tindakan dalam sebuah novel. Terkait dengan musik dalam pembelajaran, yang tujuannya adalah untuk menanamkan ideology nasional dan semangat perjuangan terhadap siswa usia sekolah dasar, maka music (lagu-lagu cinta tanag air dan perjuangan) yang dapat diintegrasikan ke dalam pembelajaran, di antaranya adalah Bagimu Negeri; Berkibarlah Benderaku; Bendera Merah Putih; Bangun Pemuda Pemudi; Dari Sabang Sampai Merauke; Garuda Pancasila; Gugur Bunga; Hari Merdeka; HaloHalo Bandung; Indonesia Mutiaraku; Indonesia Raya; Indonesia tanah air beta; Indonesia Tetap Merdeka; Maju Tak Gentar; Satu Nusa Satu Bangsa; Syukur, dan sebagainya. Melaui apresiasi langsung terhadap lagu-lagu tersebut secara perlahan tetapi pasti semangat juang para pendiri bangsa Indonesia ini akan dapat ditularkan kepada generasi penerus bangsa ini.

Berdasarkan analisis hasil penelitian yang diperoleh dari para pakar musik, ditemukan pemahaman bahwa peranan musik dalam pembentukkan budi pekerti sangat kuat. Kesimpulan ini muncul berdasarkan analisis sejarah dan analisis mekanisme terjadinya perilaku. Musik memiliki pengaruh yang cukup kuat terhadap fisik dan mental individu serta karakter masyarakat. Secara garis besar peran musik dalam pembentukan perilaku adalah sebagai basic character building atau dengan kata lain musik berperan sebagai "pondasi" dalam pembentukan budi pekerti, pembentuk perasaan moral dan pembentuk perilaku keadilan, cinta kasih dan kelemahlembutan. Musik dan budi pekerti memiliki keterkaitan yang kuat dalam prinsip keindahan, prinsip harmoni, dan prinsip ukuran dan proporsi.

Dunia pendidikan, khususnya pendidikan anak usia dini hendaknya mulai mencermati fenomena ini dan mulai memilih serta memanfaatkan musik sebagai bagian dari programprogram pembelajaran. Karena dengan mendengarkan, mengapresiasi dan menikmati musik yang baik, dapat memberikan dampak potensial yang cukup besar dalam membantu meningkatkan kualitas sumber daya manusia. Musik banyak sekali memberikan kontribusi bagi perkembangan dan keseimbangan rasional, emosional, intelektual dan kesadaran estetis.

Banyak sekali hasil penelitian yang memberikan informasi tentang pentingnya pendidikan seni khususnya musik bagi perkembangan anak, berikut beberapa hasil penelitian yang dirangkum dalam Bulletin of the Council for Research in Music Education, di antaranya adalah sebagai berikut. 1) Pendidikan musik/pendidikan seni, memudahkan perkembangan anak dalam bahasa dan kecepatan membaca. 2) Aktivitas bermusik/berkesenian sangat bernilai bagi pengalaman anak dalam berekspresi dan lain-lain. 3) Aktivitas bermusik/berkesenian membantu perkembangan sikap positif terhadap sekolah dan mengurangi tingkat ketidakhadiran siswa di sekolah. 4) Keterlibatan dalam kegiatan bermusik/berkesenian secara langsung mempertinggi perkembangan kreativitas. 5) Pendidikan musik/pendidikan seni memudahkan perkembangan sosial, penyesuian diri, dan perkembangan intelektual.

Dari penjelasan-penjelasan di atas, ternyata musik sangat penting untuk perkembangan anak di masa depan. Musik tidak lagi sebagai mata pelajaran tambahan yang sewaktu-waktu bisa saja dihilangkan atau hanya sekedar pengisi waktu luang bagi anak-anak yang kursus musik. Terkait dengan itu, maka music merupakan sesuatu hal yang penting untuk membantu siswa dalam mengembangkan intelektual, emosional dan potensi-potensi yang ada dalam diri mereka. Hal ini merupakan salah satu tugas para pendidik untuk mewujudkan hal tersebut. Maka dari itu, music dalam pendidikan merupakan bagian penting yang apabila dimanfaatkan secara tepat akan secara efektif memberikan konstribusi yang berharga dalam mewujudkan tujuan pendidikan nasional. Untuk itu, maka melalui penelitian ini, akan dikembangkan model penanaman ideology nasional dan semangat perjuangan memlalui 
232 Seni Musik serta Hubungan Penggunaan Pendidikan Seni Musik untuk Membentuk Karakter Peserta Didik di Sekolah Dasar - Tri Juna Irawana, Desyandri

pembelajaran dengan mengintegrasikan music (lagu-lagu cinta tanah air dan perjuangan) pada tingkat sekolah dasar.

\section{KESIMPULAN}

Berdasarkan uraian di atas Pendidikan Seni Musik merupakan pendidikan yang memberikan kemampuan mengeskpresikan diri dengan tujuan pengembangan kepribadian diri dan dengan musik siswa akan dengan mudah mengungkapkan perasaaan. Dengan berperan aktif dalam kegaitan seni musik, siswa dapat memngembangkan kreativitas, musik akan membantu membentuk karakter perkembangan siswa, membangun rasa keindahan, mengungkapkan ekspresi, melatih kejujuran, kedisiplinan dan berpikir kreatif.

\section{DAFTAR PUSTAKA}

ah, Lely. 2016. "Musik Dalam Pembelajaran." EduHumaniora | Jurnal Pendidikan Dasar Kampus Cibiru.

Aminah, Siti. 2016. "Pengaruh Musik Islami Terhadap Perkembangan Bahasa Anak." Jurnal Pemikiran dan Pendidikan Islam.

Atmojo, Dimas Tri. 2018. "Konsep Pendidikan Karakter Dalam Buku Pribadi Hebat Karya Buya Hamka Serta Implikasinya Pada Pembelajaran Bahasa Dan Sastra Indonesia Di SMA."

Darmawati, Darmawati and Sundari Sundari. 2016. "PENGEMBANGAN BAHAN AJAR BERBASIS NILAI KARAKTER DI SD KOTA TERNATE PROVINSI MALUKU UTARA." Jurnal Pemikiran Dan Pengembangan Sekolah Dasar (JP2SD) 1(4):243.

Halimah, Lely. 2016. "Musik Dalam Pembelajaran." EduHumaniora | Jurnal Pendidikan Dasar Kampus Cibiru.

Koesoema, Doni. 2007. Pendidikan Karakter: Strategi Mendidik Anak Di Zaman Global.

Manurung, Nixon. 2015. "Jurnal Seni Musik." Jurnal Seni Musik 4(1):16-25.

Murniyetti, Murniyetti, Engkizar Engkizar, and Fuady Anwar. 2016. "POLA PELAKSANAAN PENDIDIKAN KARAKTER TERHADAP SISWA SEKOLAH DASAR." Jurnal Pendidikan Karakter.
Respati, Reza. 2015. "Esensi Pendidikan Seni Musik Untuk Anak.” Saung Guru. 